\title{
The Chironomidae collection at the Zoological Institute (St Petersburg): history, current state and role for further research
}

\author{
Andrey Przhiboro
}

\begin{abstract}
Przhiboro A. 2012. The Chironomidae collection at the Zoological Institute (St Petersburg): history,
\end{abstract} current state and role for further research. Fauna norvegica 31: 195-203.

\begin{abstract}
This paper briefly reviews the collection of Chironomidae (Diptera) housed at the Zoological Institute of Russian Academy of Sciences in St Petersburg (ZIN). Although it is the oldest and one of the largest Chironomidae collections in Russia, most of the collection has been unknown to specialists for decades. The collection consists of three main parts: dry specimens (about 20000 pinned adults), material in ethanol (over 25000 vials with larvae, pupae and adults) and permanent slides (over 12000 slides with larvae, pupae and adults). Based on a study of the collection itself, published sources and archival data, major periods for the formation of the collection are here described. Collectors and expeditions, whose contributions were most important, are listed, as well as the regions where the material was collected. The role of chironomid researchers, who made important contributions to the creation, enrichment or study of the collection, is also described. The contributions by Aleksei Chernovskii and Vera Pankratova are considered in more detail. According to a preliminary estimate, the collection contains type specimens of no less than 150 species described by 24 authors, and thousands of specimens determined by experts. The Chironomidae collection of ZIN is particularly important because it hopefully will enable us to correctly interpret many species names proposed in 1930-1980's, mostly based on brief descriptions of larvae and currently often considered nomina dubia. In addition, the collection includes the unprocessed material from vast territory of the former Soviet Union, including many distant regions, which are still difficult to access.
\end{abstract}

doi: 10.5324/fn.v31i0.1402. Received: 2011-10-31. Accepted: 2012-03-27.

Published on paper and online: 2012-10-17.

Keywords: Diptera, collection, history, taxonomy, fauna, type material

1. Zoological Institute, Russian Academy of Sciences, Universitetskaya nab. 1, St Petersburg 199034, Russia

E-mail: dipteran@mail.ru

\section{INTRODUCTION}

The Chironomidae is one of the largest families of Diptera, with about 1500-3500 species in the Palaearctic region (Makarchenko 2006; Pape et al. 2009). The Chironomidae collection of the Zoological Institute (ZIN) of Russian Academy of Sciences in St Petersburg is the oldest and one of the largest chironomid collections in Russia, by the number of specimens, geographical coverage and the number of type specimens. This collection is a result of the work by many collectors, expeditions and experts. Among the collectors were many well-known travellers, naturalists, entomologists and hydrobiologists. Nevertheless, most of this collection has remained unknown to chironomid researchers for a long time.
History and development of the Chironomidae collection at ZIN The collection consists of three main parts:

1. Dry specimens: about 20000 pinned adults in 64 drawers; several hundred specimens are accompanied by microslides of the genitalia in Canada balsam. The microslides are pinned under each respective exemplar.

2. Material in ethanol: over 25000 vials containing mostly larvae, but also pupae and adults.

3. Permanent slides: over 12000 slides, mostly with larvae, pupae or reared adults; as a rule, in Canada balsam or Berlese fluid. (In addition, about 1000 caryological slides of chironomid larvae belonging to ca. 75 species are kept as a separate 
collection, in the Caryology Department of ZIN).

The dry collection of Chironomidae was founded at the Zoological Museum of the Russian Academy of Sciences in St Petersburg (later, the Zoological Institute of the USSR Academy of Sciences in Leningrad) in mid nineteenth century, but most of the material was collected in the late nineteenth century up to the 1960's. The collection in ethanol was organized in early twentieth century, and the collection of slides, in the 1920's. The parts of the collection are interrelated as many series are split in three parts. (For example, immatures of the same series may be kept in ethanol and slide-mounted; some of these immatures were reared to adults, which were kept in ethanol or dry, or slide-mounted). Unfortunately, no catalogue of any of these parts of the collection has been found at the present time although there is evidence from manuscripts by Chernovskii and labels on some drawers that a catalogue has existed.

The history of the collection began in 1837-1838, when the museum bought a part of the insect collection of Joseph Waltl. In this collection, Diptera was determined by J.W. Meigen (see Nartshuk 1998 for details). At present, the collection includes nine chironomid specimens with the following Meigen's labels: "Chiron. elegans", "Chiron. riparius", "Chiron. obscurus", "Chironom. aprilinus", "Chiron. aprilinus q", "Chiron. scutell. @”, "Chiron. stercorarius", "Chiron. rufipes", "Chiron. silvestris". Starting from the mid nineteenth century, the museum acquired chironomids from the collections of several noted entomologists, primarily E.F. Eversmann (161 specimens from the Volga area), C.R. Osten-Sacken (75 specimens, many of which are from the collection of P.C. Zeller and bear his labels with identifications) and F. Kowarz (106 specimens including 50 with identification labels by M. Nowicki). The chironomid specimens from the three latter collections originate from Western Europe.

In addition, there are several tens of chironomids collected in 1850-1880's by other individuals, including no less than 20 specimens with identification labels by Édouard Ménétries, the first curator of entomological collection of the Zoological Museum in mid nineteenth century. All of these and most of the other "old" chironomids are kept in a separate drawer. Apparently, the material of the nineteenth century does not include type specimens.

The first material of high importance was collected by the Russian Polar Expedition (1900-1903) headed by Edward Toll. This expedition made the first major collections of Diptera in Arctic Siberia, on the Taimyr Peninsula, the Novosibirskie Islands, and in continental Yakutia near the coast (Kharaulakh Range). The material collected by five researchers (A.A. Birula, M.I. Brusnev, K.A. Volossovich, A.V. Kolchak and P.V. Olenin) in extreme conditions of Arctic Siberia, soon was processed and published by the Finnish dipterist Carl August Lundström. He recorded 31 species of chironomids including two genera and 15 species described as new to science (Lundström 1915). About 80 years later, O.A. Sæther partially revised this part of the collection (Sæther 2004). At present, the dry collection includes
175 chironomid specimens collected by the Russian Polar Expedition; seventy pinned specimens were slide mounted, and Sæther designated lectotypes from these exemplars. (In addition, about 115 adult chironomids determined by Lundström to genus or species are stored in two jars in ethanol). During the course of the present study, the original pencil drawings made by Lundström for his paper were recovered. These are now deposited to the archive of ZIN.

Starting from the 1890's, the amount of material and the number of collectors increased rapidly. The material was collected in various regions of Russia and adjacent countries, including many distant areas, which are still difficult to access. These include many localities of the Far North, Siberia, Middle Asia, Russian Far East and Mongolia. In total, about 20000 chironomid adults are kept in 50 wooden drawers of standard size $(37 \times 42 \mathrm{~cm})$ and in 14 drawers of other sizes.

In total, some hundred persons contributed to the collection. The persons who contributed most to the dry collection, each providing a large amount of specimens, are listed in Table 1. The list of collectors who worked in hard-to-reach areas of the Far North and the Far East is most indicative. It is given in Table 2.

The collection in ethanol was developed in parallel with the dry collection. ZIN acquired numerous collections made by different expeditions, mainly the larvae collected by hydrobiologists. Main part of the material was collected in the 1930 's and in the 1950-1960's. Persons and/or expeditions who provided the most of ethanol samples are listed in Table 3.

The third part of the collection, the permanent slides, was created mainly from the 1930's. This part of the collection, as well as the Chironomidae research in ZIN, is above all associated with the names of A.A. Chernovskii and V.Ya. Pankratova. Starting from the 1920's, Aleksander von Stackelberg played a key role in the development of the Diptera collection in ZIN. In the 1930's, Aleksei Aleskeevich Chernovskii (19041942), whose supervisor was Stackelberg, in fact created the collection of Chironomidae: From the mid 1920's to the mid 1930's, Chernovskii worked at several scientific institutions, mostly as hydrobiologist-benthologist. In the early 1930's, he started working with the fauna and taxonomy of Chironomidae. Chernovskii joined the ZIN staff in 1938, worked at ZIN as short as for four years and perished during the blockade of Leningrad in February 1942, at the age of 37 (Stackelberg 1949). Over the few years, Chernovskii created the basis of the Chironomidae collection and provided no less than a quarter of the material himself. He became the first high quality expert on this group in Russia, and one of the founders of morphological studies of chironomid larvae and their diagnostics. Chernovskii studied all stages of the life cycle and regularly reared immatures to adults. Before his death, Chernovskii finished the manuscript of his key to the larvae of Chironomidae (mostly based on the material from the European part of the Soviet Union), but unfortunately he did not have the time to prepare a key to adults. A.A. Stackelberg kept the manuscript and finalized it for 
Table I. Collectors who contributed the most to the dry collection of Chironomidae at the Zoological Institute, St Petersburg. The names of collectors are in alphabetic order; initials are in brackets if they were identified tentatively from indirect evidence. Geographical names are mostly those used at the times of sampling. "Terr." is used for the Russian "Krai", "Prov.", for "Oblast"” or "Guberniya".

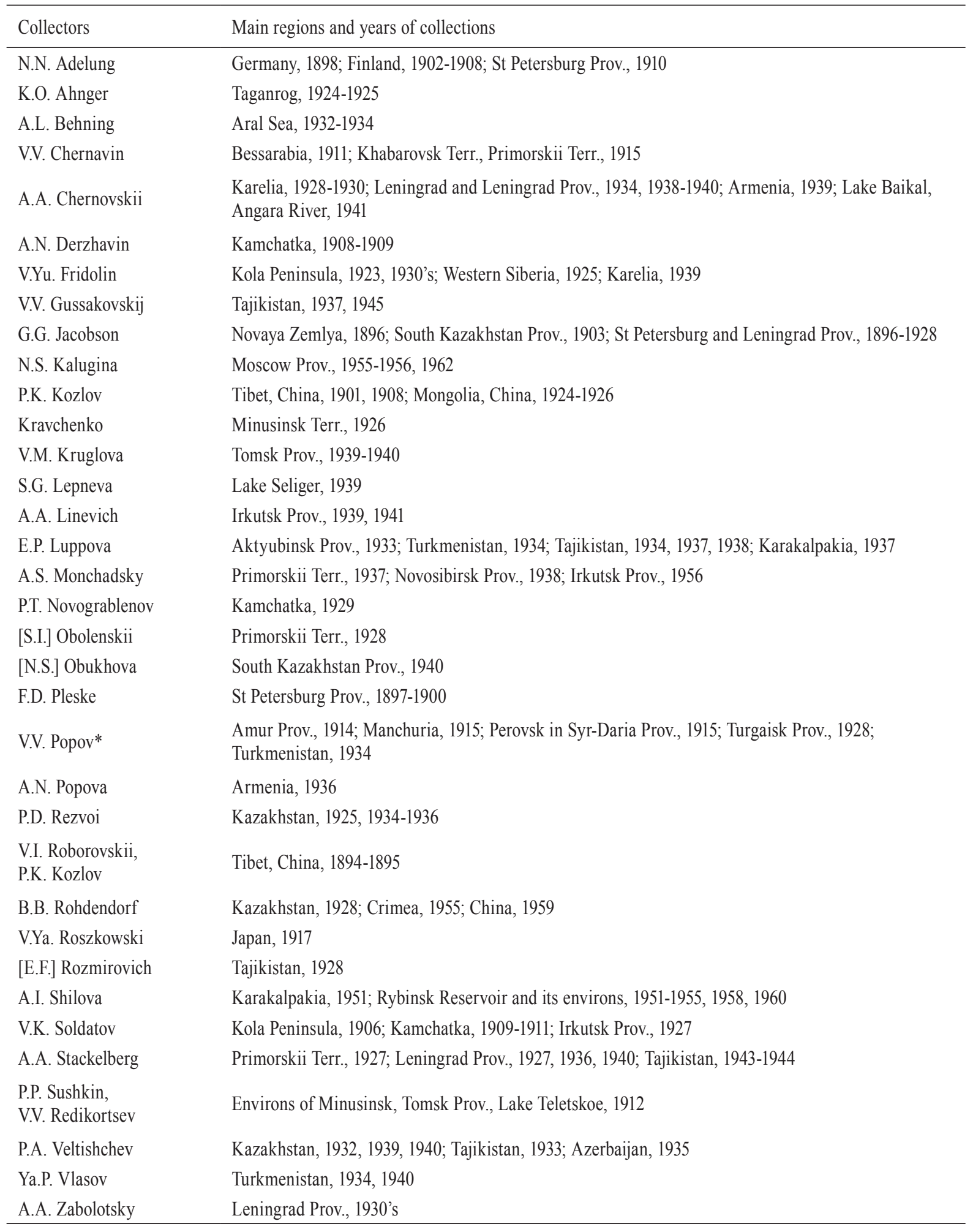

*A part of specimens was collected in 1914-1915 by N.O. Olenev and V.V. Popov. 
Table 2. Collectors from distant areas of the Far North and Far East who contributed to the dry collection of Chironomidae at the Zoological Institute, St Petersburg. Explanations as in Table 1. Names listed in Table 1 are not included.

\begin{tabular}{|c|c|}
\hline Collectors & Regions or localities and years of collections \\
\hline E.L. Abakumova & Yugorskii Shar, 1921 \\
\hline L.E. Arens & Malozemel'skaya Tundra, 1934 \\
\hline L.V. Bianchi & Environs of Yakutsk and Yst'-Kut, 1925-1926 \\
\hline A.A. Birula & Solovetskie Islands and Arkhangelsk, 1896; Spitzbergen, 1899; Kola Peninsula, 1904 \\
\hline Bordonos & Kamchatka, 1932 \\
\hline A.A. Bunge & Spitzbergen, 1900 \\
\hline [S.A.] Buturlin & Kolyma, 1905 \\
\hline N.M. Cheburova & Arkhangelsk and Murmansk provinces, 1928-1930 \\
\hline Drzewiecka & Ekaterininskii Island at Murman, 1898 \\
\hline Expedition of AKI & Indigirka River, 1929 \\
\hline I.[N.] Filip'ev & Kola Peninsula, 1914 \\
\hline A.N. Formozov & Kharlov Island at Murman, 1929 \\
\hline R.F. Gekker & Vrangel Island, 1938 \\
\hline B.N. Gorodkov & Novosibirskie Islands, 1947 \\
\hline K.B. Gorodkov & Kamchatka, 1959; Chukotka, 1963 \\
\hline K.Ya. Grunin & Norilsk, 1967 \\
\hline E.F. Gurjanova & Kamchatka, 1930 \\
\hline F.F. Il'yin & Kola Peninsula, 1901 \\
\hline V.A. Kapustin & Kola Peninsula, 1924, 1926 \\
\hline S.V. Kerzelli & Bol'shezemelskaya Tundra, 1908; Anadyr, 1930 \\
\hline Kishkin & Solovetskie Islands, 1932 \\
\hline [V.S.] Korotkevich & Dikson, Pravdy, Bol'shevik and Russkii islands, 1948 \\
\hline B.V. Koshkin & Kamchatka, 1933 \\
\hline V. Kuznetsov & Kola Peninsula, 1923 \\
\hline A.T. Lepin & Novaya Zemlya, 1935 \\
\hline Lobek & Kola Peninsula, 1928 \\
\hline A.V. Maksimov & Berezov, 1928 \\
\hline [V.G.] Mizin & Taimyr Peninsula, 1915 \\
\hline N.N. Moskvin & Yakutsk, 1927 \\
\hline S.P. Naumov & Gydanskii Peninsula, 1927 \\
\hline G.D. Richter & Bol'shezemelskaya Tundra, 1921 \\
\hline K.F. Rozhnovskii & Yakutia, 1905 \\
\hline V.A. Sapozhnikov & Kamchatka, 1909 \\
\hline R.G. Schmidt & Novaya Zemlya, 1900 \\
\hline V.M. Sdobnikov & Novosibirskie Islands, 1948 \\
\hline I.N. Shukhov & Obdorsk, 1914 \\
\hline S.K. Skribova & Novaya Zemlya, 1913 \\
\hline A.N. Smesov & Novosibirskie Islands, 1929 \\
\hline [I.K.] Sokolovskii & Novaya Zemlya, 1904 \\
\hline Sosnovskii & Novaya Zemlya, 1910 \\
\hline L.[M.] Starokadomskii & Koluma mouth, 1912; Taimyr, 1913 \\
\hline S.D. Timofeev & Novaya Zemlya, 1901 \\
\hline I.P. Tolmachev & Khatanga, 1905 \\
\hline N.M. Vakulenko & Novaya Zemlya, 1925 \\
\hline Vereshchagin & Kamchatka, 1909 \\
\hline [K.E.] Vorob'eva & Onega Distr., 1929; Bol'shezemelskaya Tundra, 1933 \\
\hline Yakovlev & Taimyr Peninsula, Khatanga River and Khatanga Bay, 1933 \\
\hline F.A. Zaitsev & Kara Tundra in Tobolsk Prov., 1909 \\
\hline A.V. Zhuravskii & Pechora River, 1904; Pechora Delta, 1907 \\
\hline
\end{tabular}


Table 3. Collectors and expeditions that contributed the most to the ethanol collection of Chironomidae at the Zoological Institute, St Petersburg. Explanations as in Table 1.

\begin{tabular}{|c|c|}
\hline Collectors and expeditions & Main regions and years of collections \\
\hline $\begin{array}{l}\text { Baikal Expedition of the USSR Academy of Sciences (in } \\
\text { 1920's, G.Yu. Vereshchagin) }\end{array}$ & Lake Baikal, 1926-1928, 1954 \\
\hline $\begin{array}{l}\text { Bol'shezemelskaya, Kara and Pechora expeditions by the } \\
\text { Arctic Institute }\end{array}$ & $\begin{array}{l}\text { Eastern continental parts of the European Far North of Russia, 1932- } \\
1933\end{array}$ \\
\hline A.T. Buldovskii & Lake Khanka, 1932-1936 \\
\hline $\begin{array}{l}\text { Caspian Expedition of the USSR Academy } \\
\text { of Sciences (Petrov, P.D. Rezvoi) }\end{array}$ & Caspian Sea, 1935 \\
\hline A.A. Chernovskii & Lakes and rivers of Leningrad Prov., 1933, 1937, 1938; Baikal, 1941 \\
\hline $\begin{array}{l}\text { Expeditions by the All-Union Scientific Institute of Lake } \\
\text { and River Fish Industry }\end{array}$ & Rivers of the upper Volga basin, 1936-1939 \\
\hline Expeditions by the State Hydrological Institute & Lakes of the Karelian Isthmus, 1933, 1934, 1936; Yakutia, 1932 \\
\hline G.M. Fridman & Lake Sevan, 1938 \\
\hline Issyk-Kul Expedition (? L.S. Berg) & Lake Issyk-Kul, 1929 \\
\hline Kama Biological Station (Grachev, V.V. Gromov) & Kama River, 1929, 1934, 1936, 1940 \\
\hline A.G. Kasymov & Krasnodar Terr., 1951-1954 \\
\hline V.M. Kruglova & Tomsk Prov., 1939 \\
\hline Ya. Lapinskaite & Latvia, 1955-1956 \\
\hline D.A. Lastockin & Moscow Reservoir, 1937-1938 \\
\hline S.G. Lepneva & Lake Teletskoe, 1930, 1931, 1934; Lake Seliger, 1939 \\
\hline E.P. Luppova & Tajikistan, 1935, 1937-1940 \\
\hline ? N.O. Olenev & Turkmenistan, 1940 \\
\hline Olonets Scientific Expedition & Southern and central Karelia, 1920-1921, 1936 \\
\hline V.Ya. Pankratova & $\begin{array}{l}\text { Aral Sea, 1932; Tajikistan, 1942-1943; Kalinin Prov., 1949-1950; } \\
\text { Latvia, 1955-1957; Turkmenistan, 1950’s; Abkhazia, 1950ies; } \\
\text { Krasnodar Terr., 1951-1954; Lake Otradnoe in Leningrad Prov., } \\
\text { 1957-1961; Ropsha springs in Leningrad Prov., 1960; Kaliningrad } \\
\text { Prov., 1961-1963; lakes of Karelia and Murmansk Prov., 1969-1972 }\end{array}$ \\
\hline Yu.V. Perwolf & Lakes of Crimea, 1932, 1938 \\
\hline ? A.N. Popova & Rivers of Armenia, 1936 \\
\hline N.I. Semenovich & Lakes of Karelia, 1933 \\
\hline V.I. Shadin & $\begin{array}{l}\text { Lake Ladoga, 1931-1938; Lake Velikoe, 1932; Neva River, 1936, } \\
\text { 1939-1940; Volga River, 1939; Lake Il'men', } 1940\end{array}$ \\
\hline G.A. Stal'makova & Kalinin Prov., 1949 \\
\hline A.I. Yankovskaya & $\begin{array}{l}\text { Tajikistan, 1948, 1959; Kyrghyzstan, 1947, 1960, 1976; Uzbekistan, } \\
\text { 1946, } 1962\end{array}$ \\
\hline A.A. Zabolotsky & Leningrad Prov., 1933-1940 \\
\hline L.A. Zhiltsova & Teberdinskii Nature Reserve, 1954 \\
\hline
\end{tabular}


Table 4. A summary of the data on type specimens of Chironomidae found in the collection of the Zoological Institute, St Petersburg. The list is preliminary and probably incomplete. Abbreviations for the status of type specimens: H, holotype; S, syntype; L, lectotype; P, paratype; PL, paralectotype.

\begin{tabular}{|c|c|c|c|c|c|}
\hline \multirow[b]{2}{*}{ Authors } & \multirow{2}{*}{$\begin{array}{l}\text { Species } \\
\text { number }\end{array}$} & \multicolumn{3}{|c|}{ Type specimens } & \multirow[b]{2}{*}{ Regions } \\
\hline & & $\begin{array}{c}\text { dry } \\
\text { (pinned) }\end{array}$ & $\begin{array}{c}\text { slide- } \\
\text { mounted }\end{array}$ & $\begin{array}{l}\text { in } \\
\text { ethanol }\end{array}$ & \\
\hline F.A. Akhrorov & 14 & & $\mathrm{H}, \mathrm{P}$ & & Tajikistan \\
\hline S.I. Belyanina & 1 & & S & & Saratov Prov. \\
\hline A.A. Birula & 9 & & & S & European North (Arkhangelsk Prov.) \\
\hline A.A. Chernovskii & 52 & S,PL & H,S,L,PL & S,PL & many regions of the former Soviet Union \\
\hline B.A. Dzhvarsheishvili & 1 & & & $\mathrm{H}, \mathrm{P}$ & Georgia \\
\hline M. Goetghebuer & 11 & $? \mathrm{H}, \mathrm{S}$ & & & Kamchatka, Primorie, Leningrad Prov. \\
\hline B.L. Golubev & 1 & & $\mathrm{P}$ & & Latvia \\
\hline O.V. Golubeva & 1 & & $\mathrm{H}, \mathrm{P}$ & & Yaroslavl Prov. \\
\hline I.I. Greze & 2 & & S & S & Irkutsk Prov. \\
\hline V.V. Gromov & 1 & & S & S & Perm Prov. \\
\hline N.S. Kalugina & 1 & $\mathrm{P}$ & & & Moscow Prov. \\
\hline A.G. Kasymov & 1 & & S & & Azerbaijan \\
\hline M.Ya. Kirpichenko & 1 & & S & & Tatarstan \\
\hline V.M. Kruglova & 2 & PL & S,L,PL & S,PL & Tomsk Prov. \\
\hline A.A. Linevich & 1 & & S & & Irkutsk Prov. \\
\hline N.V. Loginova (Polukonova) & 1 & & S & & Saratov Prov. \\
\hline C.A. Lundström & 15 & PL & H,S,L,PL & S & Arctic Siberia \\
\hline V.Ya. Pankratova & $>20$ & & H,S,L,PL & $\mathrm{S}, \mathrm{PL}$ & many regions of the former Soviet Union \\
\hline V. Romaniszyn & 1 & & $\mathrm{~S}$ & S & Leningrad Prov., Poland \\
\hline O.A. Sæther & 1 & & $\mathrm{H}, \mathrm{P}$ & & Arctic Siberia \\
\hline A.I. Shilova & 8 & $\mathrm{H}, \mathrm{P}$ & $\mathrm{H}, \mathrm{P}$ & $\mathrm{H}, \mathrm{P}$ & $\begin{array}{l}\text { Uzbekistan, Georgia, Kazakhstan, } \\
\text { Yaroslavl and Moscow provinces }\end{array}$ \\
\hline L.E. Sigareva & 1 & & S & & Saratov Prov. \\
\hline N.I. Zelentsov & 1 & & $\mathrm{H}, \mathrm{P}$ & & Yaroslavl Prov. \\
\hline O.S. Zvereva & 2 & & S & S & Komi Republic \\
\hline
\end{tabular}

publication after the war, jointly with V.Ya. Pankratova.

The ZIN collection includes about 950 slides made by Chernovskii (all are in Canada balsam). Most of the slides are arranged by subfamily and tribe and kept in 12 boxes with respective labels hand-written by Chernovskii (4 larger and 9 smaller boxes). A small number of Chernovskii's slides (92) are presently kept in other boxes, together with the slides by V.Ya. Pankratova (see below). Most of Chernovskii's slides are with larvae only; there are slightly more than 150 slides with adults and about 100 slides with pupae. Most slides include several specimens attributed to the same species and most slides are supplied by paper labels hand-written by Chernovskii. As a general rule, the labels include Chernovskii's identifications.

A part of the larvae and many adults kept in ethanol were also identified by Chernovskii. He arranged a part of this material in ethanol by genus, leaving the other part is organized by the collection localities. Some thousands of adults in the dry collection also bear identification labels by Chernovskii. Many of these specimens have microslides of the genitalia. In addition, the genitalia of some specimens (those with a red circle on the pin) were slide-mounted and kept separately.

Judging from the labels, some adults kept in ethanol or dry were reared from immatures. However, in most cases the larval and pupal exuviae cannot be located and it is possible to tentatively associate the larvae corresponding to the reared adults mostly based on the labels alone.

Along with his own material, Chernovskii worked with chironomids collected by many colleagues. Major collectors of the material (larvae and reared adults) examined by Chernovskii are: B.M. Aleksandrov, G.M. Fridman, V.Yu. Fridolin, V.V. Gromov, Ts.I. Ioffe, V.M. Kruglova, E.P. Luppova, D.I. Murvanidze, E.S. Neizvestnova-Shadina, Yu.V. Perwolf, V.I. 
Shadin, A.A. Zabolotsky. The list is based on the labels on Chernovskii's slides.

A.A. Chernovskii described over 70 new species in Chironomidae; 52 species-group names are available according to the International Code of Zoological Nomenclature (ICZN). Type specimens of species described by Chernovskii are kept in all three parts of the ZIN collection. Some types of almost all of his species are slide-mounted, and probably it is the material that Chernovskii used to first describe larvae. In general, type specimens are not labelled as types, except for some pinned adults that are indicated as types by a black circle on the pin.

In 2009, a folder with the manuscript of A.A. Chernovskii's book (Chernovskii 1949) was found in ZIN. In addition to the manuscript of the book, the folder contains a brief hand-written catalogue of the material of larvae, on which the Chernovskii's new species are based.

After Chernovskii, starting from 1950's, Vera Yakovlevna Pankratova(1908-1991)contributed considerably to the collection and to the chironomid research in the Soviet Union. She worked at ZIN from 1938 to the early 1980's. Pankratova began to study chironomid faunistics and ecology in the 1930's. Later on, she combined this research with taxonomy through participation in the studies of lake and river ecosystems conducted by the Laboratory of Freshwater Hydrobiology, where she worked. In most water bodies studied, Pankratova investigated mainly immatures and did not rear adults. Unfortunately, her new taxa were described only from immatures.

The ZIN collection holds about 11000 slides made by Pankratova, including some hundred thousand chironomid specimens, mostly larvae. Several hundred slides of pupae and adults are also present. The vast majority of the slides are in Berlese fluid and many of them are damaged from dryingout; some of the slides made in the 1930's to the early 1950's apparently are in Canada balsam. Generally, the labels are written with ink on glass and include identifications. In many slides, larvae of different genera and subfamilies are mounted alongside, apparently because these slides were made during the identification of chironomids from quantitative benthic samples. The slides are kept in 48 boxes, mostly arranged by the regions and water bodies. In addition, a part of the material collected and partially examined by Pankratova in all periods of her work is kept in ethanol.

Major collectors of the material (larvae and reared adults) examined by Pankratova are: N.A. Akatova, A.F. Alimov, T. Bystrova, Dulmaa, E.A. Erbaeva, Z.I. Filimonova, N.P. Finogenova, V.V. Gurvich, M.A. Ivanova, T.S. Kats, I.I. Kornoukhova, V.S. Korotkevich, V.Ya. Levanidov, A.M. Mukhamediev, Nguen Van Hong, V.I. Shadin, N.V. Shadrin, V.N. Shubina, F.I. Shchurakov, G.A. Stal'makova, S.J. Tsalolikhin, L.V. Vasil'eva, S.V. Vassilenko, T.A. Vlasova, A.I. Yankovskaya. The list is based on the labels on Pankratova's slides.

V.Ya. Pankratova described over 80 new species in Chironomidae, but only 37 species names are available. Many names proposed by Pankratova, similar to those by Chernovskii, are unavailable according to the ICZN, because the species were not assigned (even tentatively) to genera. Type specimens of species described by Pankratova are mostly slide-mounted and not labelled as types, some putative types are also stored in ethanol.

One of the most significant results of the work by V.Ya. Pankratova is her three-volume monograph on the larvae and pupae of Chironomidae of the Soviet Union (Pankratova 1970, 1977a, 1983). This work includes keys, descriptions of new species, redescriptions of many larvae and pupae, and contains the data on distribution and bionomics of chironomids. Pankratova made a huge effort to study the faunal composition of chironomid larvae in various standing and running waters. These results have been published in numerous hydrobiological papers and monographs with her participation, and specimens from the studies are adequately represented in the slide collection.

Many other specialists on the Chironomidae have contributed to the ZIN collection. Maurice Goetghebuer, a Belgian dipterist, described in 1928-1942 no less than 26 chironomid species from adults collected in the former Soviet Union, mostly by A.A. Stackelberg, A.A. Zabolotsky and N.K. Deksbach. Types of eleven of these species are found in the ZIN collection. In addition, several hundred chironomids in the dry collection bear Goetghebuer's identification labels.

In the 1930's, the collection acquired the material by V.M. Kruglova, V.V. Gromov and A.A. Birula (Bialynicki-Birula), including the types of their new species. In the 1950-1980's, several experts worked with the collection. Among them were A.I. Shilova, A.A. Linevich, N.S. Kalugina, T.A. Muragina (Koreneva), N.I. Zelentsov and E.A. Makarchenko. Type specimens of many new species were deposited in ZIN. At present, the collection includes types of no less than 150 species described by 24 authors (Table 4). This number results from the examination of the collection itself (especially, the labels) and the publications. The status of some specimens needs clarification, considering that many types are not labelled in a proper way. Five genera are based on the type species with primary types kept in ZIN collection: Acalcarella Shilova, 1955; Arctodiamesa Makarchenko, 1983; Arctomyia Lundström, 1915; Lipiniella Shilova, 1961; Stackelbergina Shilova \& Zelentsov, 1978.

Since the 1970's, only a minor part of the collection has been revised. In addition to the material described by Lundström (see above), Zelentsov (1980a, 1980b) revised a part of the type material of Psectrocladius, Pankratova et al. (1980) re-examined the material of Chironomus from Lake Sevan, and Makarchenko and Linevich revised some of the Diamesinae (Makarchenko 1985; Linevich \& Makarchenko 1989).

\section{DISCUSSION}

In summary, some hundred chironomid species were described 
from the former Soviet Union in 1920-1980's, most of them, only as larvae. Only some of these species names are currently considered as valid and some are listed as junior synonyms of other species confirmed by re-examination of types. In addition, many names are questionable or supposed junior synonyms based mainly on comparisons of descriptions, and many names are considered as nomina dubia (e.g. Ashe \& Cranston 1990; Ashe \& O'Connor 2009). In general, nomina dubia are rarely treated in taxonomic reviews and obviously not included in the lists of valid taxa (e.g. Sæther et al. 2000; Sæther \& Spies 2011). One of the reasons for the uncertain status of many species with types deposited at ZIN is that most of them were only briefly and incompletely described as larvae and cannot be reliably linked to adults. At the same time, chironomid biodiversity in many territories of the Palaearctic region is still poorly known. There have been several attempts to summarize the knowledge of and to associate the larval and adult stages of chironomid species in Russia (Sokolova \& Koreneva 1959; Miseyko 1971; Shilova 1976; Makarchenko 1985). Unfortunately, the supposed associations largely have not been based on re-examination of types.

An additional problem related to the identity and distribution of many species in Russia and adjacent regions is that the keys by Chernovskii (1949) and Pankratova (1970, 1977a, 1977b, 1983) usually were the basal (and generally the only) identification guides used in faunistic hydrobiological studies in the Soviet Union and Russia. As a result, many of the identifications given in hydrobiological papers (in particular, in faunistic works) cannot be trusted and are only tentatively comparable with similar data from water bodies situated in Western and Central Europe since taxa from these regions were identified with different and often more recent keys (e.g. Wiederholm 1983; Schmid 1993).

The Chironomidae collection at ZIN contains a valuable source of information that can enable us to correctly interpret a number of species proposed in the twentieth century and names used in the subsequent publications. Recently this has been demonstrated for two species (Przhiboro \& Sæther 2008, 2010). A re-examination of types and taxonomically relevant non-type material, especially reared but undescribed adults of species that were originally were described as immatures, could clarify the status of many taxa. The collection is also useful for the correct interpretation of published data on geographic distributions and habitats of many species as higher taxonomic resolution and correct identifications are important when chironomids and their assemblages are used as ecological indicators in assessment of water quality and in monitoring of aquatic ecosystems. The collection may be important also for assessing changes in ecosystems because it contains a considerable amount of material from many water bodies collected decades ago. Species composition of chironomids is essential for the assessment of changes in aquatic ecosystems and since earlier publications often contain inexact or erroneous identifications, re-examination of the material on which these identifications were based may play a key role. In particular, this approach was recently used to assess changes in two northern lakes (Przhiboro \& Sæther 2011).

Finally, the collection is a reservoir of additional information on the taxonomy and distribution of many species as it contains large amounts unprocessed material from distant and poorly studied regions of the Palaearctic. Many of these regions are still difficult to access and the study of already collected material may provide an opportunity to work on unknown taxa and in areas that otherwise will be white spots on the map.

\section{REFERENCES}

Ashe P, Cranston PS. 1990. Family Chironomidae. In: Soós Á, Papp L (eds). Catalogue of Palaearctic Diptera. Vol. 2 Psychodidae Chironomidae. Akadémiai Kiadó. Budapest. pp 113-355.

Ashe P, O'Connor JP. 2009. A world catalogue of Chironomidae (Diptera). Part 1. Buchonomyiinae, Chilenomyiinae, Podonominae, Aphroteniinae, Tanypodinae, Usambaromyiinae, Diamesinae, Prodiamesinae and Telmatogetoninae. The Irish Biogeographical Society. $445 \mathrm{p}$.

Chernovskii AA. 1949. Opredelitel' lichinok komarov semeistva Tendipedidae [A key to larvae of the family Tendipedidae]. Opredeliteli po faune SSSR, izdavaemye Zoologicheskim Institutom AN SSSR 31: 1-187. Izdatel'stvo Akademii Nauk SSSR. Moscow, Leningrad. [In Russian].

Linevich AA, Makarchenko EA. 1989. New and poorly known chironomid species from the subfamily Diamesinae (Diptera, Chironomidae) from Baikal and Cisbaikalia. In: Sistematika i ekologiya rechnykh organizmov [Systematics and ecology of river organisms]. Vladivostok. pp 20-36. [In Russian].

Lundström C. 1915. Résultats scientifiques de l'Expédition Polaire Russe en 1900-1903, sous la direction du Baron E. Toll. Section E: Zoologie. Volume II, livr. 8. Diptera Nematocera aus den arctischen Gegenden Sibiriens. Mémoires de l'Académie Impériale des Sciences, Classe Physico-Mathématique, Série VIII, 29(8): 1-33.

Makarchenko EA. 1985. Khironomidy Dal'nego Vostoka SSSR. Podsemeistva Podonominae, Diamesinae i Prodiamesinae (Diptera, Chironomidae) [Chironomids of the Far East of the USSR. The subfamilies Podonominae, Diamesinae i Prodiamesinae (Diptera, Chironomidae)]. Vladivostok. 200 p.

Makarchenko EA. 2006. Fam. Chironomidae - non-biting midges (introduction). In: Opredelitel' nasekomykh Dal'nego Vostoka Rossii [Key to insects of the Russian Far East]. Dal'nauka. Vladivostok. pp 204-235. [In Russian].

Miseyko GN. 1971. On the correlation between the systematics of the larvae and the imagines of Chironomidae. Limnologica 8(1): 47-48.

Nartshuk EP. 1998. On history of the Diptera collections of the Zoological Institute RAS in St. Petersburg. Trudy Zoologicheskogo Instituta RAN 276: 129-134.

Pankratova VYa. 1970. Lichinki i kukolki komarov podsemeistva Orthocladiinae fauny SSSR (Diptera, Chironomidae = Tendipedidae) [Larvae and pupae of midges of the subfamily Orthocladiinae of the USSR fauna]. Opredeliteli po faune SSSR, izdavaemye Zoologicheskim Institutom AN SSSR 102: 1-344. 
Nauka. Leningrad. [In Russian].

Pankratova VYa. 1977a. Lichinki i kukolki komarov podsemeistv Podonominaei Tanypodinae fauny SSSR (Diptera, Chironomidae $=$ Tendipedidae) [Larvae and pupae of midges of the subfamilies Podonominae and Tanypodinae of the USSR fauna]. Opredeliteli po faune SSSR, izdavaemye Zoologicheskim Institutom AN SSSR 112: 1-154. Nauka. Leningrad. [In Russian].

Pankratova VYa. 1977b. Family Chironomidae. In: Kutikova LA, Starobogatov YaI (eds). Opredelitel' presnovodnykh bespozvonochnykh evropeiskoi chasti SSSR (plankton i bentos) [A key to freshwater invertebrates of the European part of the USSR (plankton and benthos)]. Gidrometeoizdat. Leningrad. pp 371-431. [In Russian].

Pankratova VYa. 1983. Lichinki i kukolki komarov podsemeistva Chironominae fauny SSSR (Diptera, Chironomidae = Tendipedidae) [Larvae and pupae of midges of the subfamily Chironominae of the USSR fauna]. Opredeliteli po faune SSSR, izdavaemye Zoologicheskim Institutom AN SSSR 134: 1-296. Nauka. Leningrad. [In Russian].

Pankratova VYa, Chubareva LA, Petrova NA. 1980. On the systematics of species of the genus Chironomus (Chironomidae) of Lake Sevan. In: Chubareva LA (ed.). Novye dannye po kariosistematike dvukrylykh nasekomykh [New data on caryosystematics of Diptera]. Trudy Zoologicheskogo Instituta AN SSSR 95: 50-52. [In Russian].

Pape T, Bickel D, Meier R (eds). 2009. Diptera diversity: status, challenges and tools. Brill. xx, $459 \mathrm{p}$.

Przhiboro AA, Sæther OA. 2008. Orthocladius paratatricus Chernovskii, 1949 a synonym of Heterotrissocladius subpilosus (Kieffer, 1911). Zootaxa 1763: 38-40.

Przhiboro A, Sæther OA. 2010. Tvetenia tshernovskii (Pankratova, 1968), comb. n., a senior synonym of Tvetenia vitracies (Sæther, 1969) (Diptera: Chironomidae). Zootaxa 2675: 57-64.

Przhiboro A, Sæther OA. 2011. Littoral chironomid communities of two small lakes in northern Karelia (Russia) studied by emergence traps. In: Wang X, Lui W (eds). Contemporary chironomid studies. Proceedings of the 17th international symposium on Chironomidae. Nankai University Press. pp 187-217.

Sæther OA. 2004. The chironomids (Diptera, Chironomidae) described by Lundström (1915) from arctic Siberia, with a redescription of Derotanypus sibiricus (Kruglova \& Chernovskii). Zootaxa 595: 1-35.

Sæther OA, Ashe P, Murray DA. 2000. Family Chironomidae. In: Papp L, Darvas B (eds). Contributions to a manual of Palaearctic Diptera (with special reference to flies of economic importance). Appendix. Science Herald. Budapest. pp 113-334.

Sæther OA, Spies M. 2011. Fauna Europaea: Chironomidae. In: de Jong H (ed.). Fauna Europaea: Diptera: Nematocera. Fauna Europaea, version 2.4. Available from: www.faunaeur.org. Last updated: 2011-01-27. Accessed: 2011-09-20.

Schmid PE. 1993. A key to the larval Chironomidae and their instars from Austrian Danube region streams and rivers with particular reference to a numerical taxonomic approach. Part I. Diamesinae, Prodiamesinae and Orthocladiinae. Wasser und Abwasser, Supplement 3/93: 1-514.

Shilova AI. 1976. Khironomidy Rybinskogo vodokhranilishcha [Chironomids of Rybinsk Reservoir]. Nauka. Leningrad. 251 p. [In Russian].
Sokolova NYu, Koreneva TA. 1959. Biological cycles of some Tendipedidae abundant in Uchinsk Reservoir and seasonal dynamics of abundance of their larvae. Byulleten' Moskovskogo Obshchestva Ispytatelei Prirody 64(2): 67-78. [In Russian].

Stackelberg AA. 1949. Aleksei Alekseevich Chernovskii (19041942). In: Chernovskii AA. (op. cit.). pp 3-5. [In Russian].

Wiederholm T (ed.). 1983. Chironomidae of the Holarctic region. Keys and diagnoses. Part 1. Larvae. Entomologica Scandinavica, Supplement 19: 1-457.

Zelentsov NI. 1980a. Revision of the Pamirian Orthocladiinae of the genus Psectrocladius Kieff. (Diptera, Chironomidae). In: Morfologiya i biologiya presnovodnykh bespozvonochnykh [Morphology and biology of freshwater invertebrates]. Trudy Instituta Biologii Vnutrennikh Vod AN SSSR 44(47): 110-135. [In Russian].

Zelentsov NI. 1980b. Contribution to the taxonomy of the genus Psectrocladius Kieff:: the subgenus Psectrocladius s. str. Wülk. (Diptera, Chironomidae). In: Biologiya, morfologiya i sistematika vodnykh bespozvonochnykh [Biology, morphology and systematics of aquatic invertebrates]. Nauka. Leningrad. pp 193-231. [In Russian]. 